\title{
Asbestos-related lung cancers: A retrospective clinical and pathological study
}

\author{
MARIE UGUEN $^{1,2}$, JEAN-DOMINIQUE DEWITTE ${ }^{1,3}$, PASCALE MARCORELLES ${ }^{2-4}$, BRICE LODDÉ ${ }^{1,3}$, \\ RICHARD POUGNET ${ }^{1}$, PHILIPPE SALIOU ${ }^{5,6}$, MARC DE BRAEKELEER ${ }^{4,6,7}$ and ARNAUD UGUEN ${ }^{2,3,6}$
}

\author{
Departments of ${ }^{1}$ Occupational and Environmental Diseases, and ${ }^{2}$ Pathology, Brest University Hospital, University of Brest, \\ F-29220 Brest; ${ }^{3}$ European University of Brittany, F-35000 Rennes; ${ }^{4}$ Laboratory of Neurosciences of Brest (EA4685), \\ Faculty of Medicine, The University of Western Brittany; ${ }^{5}$ Department of Public Health, Brest University Hospital, \\ University of Brest, F-29220 Brest; ${ }^{6}$ Inserm, U1078; ${ }^{7}$ Department of Cytogenetics and Reproduction Biology, \\ Brest University Hospital, University of Brest, F-29220 Brest, France
}

Received June 9, 2016; Accepted January 30, 2017

DOI: $10.3892 / \mathrm{mco} .2017 .1277$

\begin{abstract}
Exposure to asbestos results in serious risks of developing mesothelioma and lung cancer. The link between asbestos exposure and lung carcinoma is well established. Nevertheless, precise histopathological data are poorly considered when investigating the asbestos-cancer link in a compensatory approach. In the present study, we aim to describe the features of individuals with compensated lung cancer who were referred to an occupational disease center, regarding occupational exposure to asbestos, smoking history and pathological data. We led a retrospective study of compensated ARLC cases seen in our occupational disease center between 2003 and 2013. A total of 146 men were included (mean age at diagnosis, 63.2 years) of whom approximately $90 \%$ were heavy current or former smokers (mean value, 30.4 packs/year). The major industries associated with the lung cancer cases were shipbuilding (69.9\%), and building construction $(7.5 \%)$ in this harbor region. The results of the present study showed that lung upper lobe was most prevalent (61.6\%) and an excess of adenocarcinoma was found (45.9\%), followed by squamous cell carcinoma (38.4\%) as well as thoracic sarcomas $(2.1 \%)$. Neoplasm was not histologically proven in $6.8 \%$ of the cases. Subsequent pathology examinations also reclassified 2 tumors as metastases from esophageal and laryngeal origins. In conclusion, smoking prevention should be encouraged in asbestos-exposed workers as reflected by the number of smokers with asbestos-related lung cancer. Thus, histological data should be considered further to evaluate the potent relationship between asbestos exposure and lung malignancy, especially in a compensatory approach.
\end{abstract}

Correspondence to: Dr Arnaud Uguen, Department of Pathology, Brest University Hospital, University of Brest, 5 Avenue Foch, F-29220 Brest, France

E-mail: arnaud.uguen@chu-brest.fr

Key words: asbestos, lung cancer, occupational health, histopathology, smoking

\section{Introduction}

Occupational lung cancer generates high mortality and is the most common cancer compensated in France (1). In 1997, the Helsinski criteria for identifying individuals with a high risk of asbestos exposure at work were accepted (2). Older studies found inconsistent results regarding the lobe of origin and histology of asbestos-related lung cancer (ARLC) (3). Some studies showed an upper lobe location similar to tobacco-related lung cancer, whereas other investigators found a lower lobe location (4-11). Although adenocarcinoma was found to be the most prevalent in some studies, a recent review of the literature by Nielsen et al (3) showed that there was no difference in location and cell type between ARLC and non-ARLC. They concluded that cell type and location of lung cancer were not useful for differentiating ARLC from other lung cancers. Prognosis of ARLC was not different from that of other lung cancers (3).

Presence of pleural plaques demonstrated a previous asbestos exposure but was not a precancerous condition. Asbestosis argued for high asbestos exposure and was associated with an increased risk of lung cancer (3). All asbestos types were associated with lung cancer (3).

Asbestos-exposed smokers had a higher risk of developing lung cancer compared with asbestos-exposed non-smokers. In fact, smoking was found to be the main risk factor but its interaction with asbestos was not totally clear (3). Some studies showed a multiplicative effect, whereas other studies suggested an additive model (12-15).

The present study investigated the occupational data of patients with compensated lung cancer, their smoking habits and histological subtype of lung cancer. The aim of the present study was also to discuss the criteria for warding occupational cancer compensation.

\section{Patients and methods}

After ethics approval was obtained from our institutional review board (CHRU Brest, 2016. CE10), we led a retrospective study based on financially compensated ARLCs identified 
Table I. Distribution of industries and jobs of patients with asbestos-related lung cancers.

One type of industrial classification inpatients' professional career

Handling of

asbestos-containing

products during their job

Handling of asbestos-containing products during their job

Handling of asbestos-containing products during their job

Using asbestos-containing products in manufacturing process
Building construction

(two job occupations quoted)

Building construction

Ship building and repair

Ship building and repair (two job occupations quoted)

Electricity/gas and steam power

Transportation services

Manufacturing plastics and rubber materials Details not provided
Bricklayer/ carpenter (5)

Plumber, sheet metal construction worker (1)

Painter (1)

Carpenter and cable setting man (1),

Crane operator (demolition waste and brake

lining assembler) and maintenance (1)

Brake lining assembler/mechanic (1)

Carpenter (11), Mechanic (29), Boiler maker and installer (1),Welder (22), Storekeeper (1),

Electricity and cable setting man (24)

Maintenance (1), Painter (1)

Details not provided (3)

Mechanic and boiler installer (1), Mechanic and carpenter (2), Carpenter and cable settingman (1), Painter and boiler installer (1), Truck driver and installer (2), Installer and storekeeper (1),

Coppersmith and mechanic (1)

Installer (1), Electricity and cable setting man (4),

Boiler installer (1), Mechanic and boiler

installer (1), Coppersmith (1)

Maintenance and repairman (1)

Mechanic (2), Electricity and cable setting

man (2),Welder (1), Working in co-activity (4)

Details not provided (1), Plumber (1), Welder (2)

Two types of industrial classification in patients' professional career

Handling of

asbestos-containing

products during their job

Handling of asbestos-containing products during their job
Building construction and ship building

Building construction and electricity/gas steam power Building construction and national defense Manufacture of motor vehicles and national defense

Ship building and national defense Ship building and water distribution installation

Ship building andmanufacture of basic iron and steel

Details not provided
Bricklayer and boiler installer (1), Maintenance and storekeeper (1), Welder (1), Carpenter and boiler installer (1), Plumber and welder (1) Mechanic, installer and boiler installer (1)

Electronics (1)

Mechanic (brake lining assembler) (1)

Painter (1)

Installer and coppersmith (1)

Welder, installer and maintenance (1)

Details not provided (2) in occupational disease center between 2003 and 2013. Data on occupational history and smoking habits were collected. Ex-smokers were defined as those who had ceased smoking at the time they consulted in our occupational disease center. Non-smokers were defined as those who had never smoked in their lifetime. Tumor location and histological subtype 
Table II. Distribution of asbestos-containing materials (no. of times where materials are quoted).

Type of asbestos-containing materials

No. of times where materials are quoted

\begin{tabular}{lc}
\hline Thermal insulation & 64 \\
Asbestos dust on equipment & 58 \\
Seal coating & 41 \\
Thermal protection workstation & 33 \\
Asbestos cement & 25 \\
Individual thermal protection & 18 \\
Waste & 17 \\
Friction linings & 11 \\
Flocking & 9 \\
Loose asbestos & 3 \\
Asbestos resin & 1 \\
Details not provided & 5 \\
\hline
\end{tabular}

of lung cancer were noted according to the last pathological data. Patients who had two occupations were recorded separately.

The present study included 146 male patients of whom the majority $(90 \%)$ were heavy current or former smokers (mean, 30.4 packs/year).

\section{Results}

Patient characteristics. In total, 146 male patients with a mean age at diagnosis of 63.2 \pm 9.9 years (range, 37-85 years) were included in the present study. Ex-smokers represented $79.5 \%(116 / 146)$ of the cohort, followed by smokers $(10.3 \%, 15 / 146)$ and non-smokers $(5.5 \%, 8 / 146)$. No data were available for $4.8 \%(7 / 146)$ of the patients. The mean consumption of ex-smokers and smokers was $30.4 \pm 16.9$ packs/year.

Work-relatedness. Ship repair was the most prevalent occupational industry $(69.9 \%, 102 / 146)$, followed by building construction $(7.5 \%, 11 / 146)$, and electricity $(4.8 \%, 7 / 146$ (Table I). The most common types of job were maintenance and repair (mechanics, 38 cases), followed by electricity and cable setting (31 cases), welder (27 cases) and boiler-related jobs (7 cases). Thirteen patients had two types of industrial classification in their professional career. Regarding the frequency of asbestos-containing materials, thermal insulation was the most prevalent ( 64 cases), followed by asbestos dust on equipment (58 cases), seal coating (41 cases), thermal protection workstation (33 cases), and asbestos cement ( 25 cases) (Table II). The mean duration of asbestos exposure for lung cancer was $28.3 \pm 10.1$ years, while the mean duration of the latency period was $10.5 \pm 8.6$ years.

Tumor localization. The tumor was located in the upper lobe in $61.6 \%(90 / 146)$ of the cases, followed by the lower lobe $(21.2 \%, 31 / 146)$, the middle lobe $(3.4 \%, 5 / 146)$, and lower and middle lobe associated with $2.1 \%$ (3/146). No data were available for $11.6 \%$ of cases (17/146).
Histological cancer type. Adenocarcinoma was the most frequent cancer $(45.9 \%, 67 / 146)$, followed by squamous cell carcinoma $(38.4 \%, 56 / 146)$, small cell lung carcinoma $(4.8 \%, 7 / 146)$, undifferentiated/sarcomatoid carcinoma lacking adenocarcinomatous or squamous differentiation $(2.1 \%, 3 / 146)$, and sarcoma (without specification 1.4\%,2/146; dedifferentiated liposarcoma $0.7 \%, 1 / 146)$. One of the undifferentiated sarcomatoid carcinoma arose in the posterior mediastinum without lung tumor. Further pathological analyses reclassified two tumors as lung metastases of an esophageal adenocarcinoma and a primary laryngeal squamous cell carcinoma. There was no histological proof of cancer in $6.8 \%$ (10/146) of the cases, diagnosis being only based on radiological data (investigations refused by the patients, non-contributive or prevented by the patients' general condition).

Compensated ARLC. Diagnostic criteria of asbestos-related diseases were established in France in 1950 and 1996 and updated in 2000 (Tables of occupational diseases 30 and 30 bis). The main recognized non-cancerous asbestos- related diseases are asbestosis (Table 30 alinea A) and pleural thickening or pleural plaques (Table 30 alinea B). Recognized asbestos-related cancers are malignant mesothelioma (Table 30 alinea D) and primary lung cancer (Table 30 alinea $\mathrm{C}$ if associated with non-cancerous asbestos-related diseases with a requirement of exposition to asbestos for $>5$ years or Table 30 bis without other asbestos-related diseases but with a requirement of exposition to asbestos for $>10$ years).

In the present study, the patients represented $52.1 \%(76 / 146)$ and $46.6 \%(68 / 146)$ of compensated lung cancers in Tables 30 and 30 bis, respectively (no data for 2 patients). In addition, $49.3 \%$ of patients had pleural plaques $(72 / 146)$ and $13 \%$ had pleural thickening (19/146), while $44.4 \%$ of the pleural plaques were located in the costo-vertebral gutters (32/72) and $12.5 \%$ on the diaphragm (9/72), 5.6\% were located on the anterior wall (4/72) and $5.6 \%$ on the posterior wall (4/72). Atelectasis strips were only evident in $2.7 \%(4 / 146)$, asbestosis in $0.7 \%(1 / 146)$ and pleurisy in $4.1 \%(6 / 146)$.

\section{Discussion}

To the best of our knowledge, this is the first comprehensive study conducted in France on occupational asbestos exposure and lung carcinoma pathological features. The link between lung cancer and asbestos exposure is sometimes difficult to attest (16). Two criteria for this recognition are used in many countries (Germany, Austria, Belgium, Finland, Norway, Sweden and Switzerland): proved intense exposure (Helsinki criteria or threshold of 25 fibers $/ \mathrm{ml} /$ year) and/or asbestos-related conditions (asbestosis and/or extensive modification of the pleura) (17). In France, occupational disease tables with specific criteria are used to determine whether or not lung cancer is asbestos-related (Tables 30 and 30 bis) or not. The diagnosis must be based on histological data or, if not available, on the basis of a clinical course and suggestive radiological data (17). Many differences regarding criteria exist between European countries for the recognition of ARLC (Table III) (17). 
Table III. European criteria for recognition of ARLC [(adapted from Eurogip. Les maladies professionnelles liées à l'amiante en Europe. 10-43. 1-1-2006).(1,17)].

\begin{tabular}{|c|c|c|c|}
\hline Country & Medical criteria & Exposure criteria & Latency \\
\hline France & $\begin{array}{l}\text { Histological examination or on the basis } \\
\text { of radiological data and clinical course }\end{array}$ & $\begin{array}{l}10 \text { years (Table } 30 \text { bis) or } 5 \text { years } \\
\text { (Table } 30 \text { alinea } C \text { ) of exposure } \\
\text { Limiting list of works }\end{array}$ & $\begin{array}{l}\text { Maximum: } 40 \text { years } \\
\text { after the end } \\
\text { of exposure }\end{array}$ \\
\hline Germany & $\begin{array}{l}\text { Lung cancer with asbestosis or pleural disease } \\
\text { Alternative condition (see exposure criteria) }\end{array}$ & $\begin{array}{l}\text { Exposure of } 25 \text { fibers/ml/year } \\
\text { (alternative condition to medical criteria) }\end{array}$ & $\begin{array}{l}10 \text { years at least } \\
\text { No details provided }\end{array}$ \\
\hline Austria & $\begin{array}{l}\text { Lung cancer with asbestosis or pleural disease } \\
\text { Alternative condition (see exposure criteria) }\end{array}$ & $\begin{array}{l}\text { Exposure of } 25 \text { fibers/ml/year } \\
\text { (alternative condition to medical criteria) }\end{array}$ & \\
\hline Belgium & $\begin{array}{l}\text { Alternative conditions: } \\
\text { Asbestosis or pleural thickening } \\
\text { Under optical microscope: } 500 \text { asbestos bodies } \\
\text { per gram of dry lung tissue or at least } 5 \text { asbestos } \\
\text { bodies per ml of bronchoalveolar lavage } \\
\text { Confirmed by electronic microscopy if doubt } \\
\text { Under electron microscope:at least } 5 \text { million } \\
\text { asbestos fibers longer than } 1 \mu \mathrm{m} \text { per gram of dry } \\
\text { lung tissue or at least } 2 \text { million amphibole fibers } \\
\text { longer than } 5 \mu \mathrm{m} \text { per gram of dry lung tissue } \\
\text { Alternative criteria (see exposure criteria) }\end{array}$ & $\begin{array}{l}\text { Exposure of } 25 \text { fibers } / \mathrm{ml} / \text { year } \\
\text { Or limitative list of works } \\
\text { Or medical criteria equivalent to } \\
\text { exposure above } 25 \text { fibers } / \mathrm{ml} / \text { year }\end{array}$ & 10 years \\
\hline Denmark & $\begin{array}{l}\text { Better microscope diagnosis, otherwise } \\
\text { probable diagnosis based on clinical } \\
\text { presentation and course of the disease }\end{array}$ & Helsinski criteria & $\begin{array}{l}\text { Details not } \\
\text { provided }\end{array}$ \\
\hline Spain & $\begin{array}{l}\text { Lung cancer with asbestosis. If no asbestosis, } \\
\text { diagnosis based on a biopsy, otherwise } \\
\text { microscopic examination of } \\
\text { the bronchoalveolar lavage }\end{array}$ & $\begin{array}{l}10 \text { years (except for } \\
\text { lung cancer with asbestosis) }\end{array}$ & $\begin{array}{c}10-20 \text { years } \\
10 \text { years (if } \\
\text { no asbestosis) }\end{array}$ \\
\hline Finland & $\begin{array}{l}\text { Diagnosis of a neoplasm of lung or bronchi by a } \\
\text { pathologist. If asbestosis, automatic recognition }\end{array}$ & Helsinski criteria (if no asbestosis) & \\
\hline Italy & $\begin{array}{l}\text { Radiologic examination (X-ray, CT-scan), blood } \\
\text { tests, electrocardiogram, cytological examination }\end{array}$ & $\begin{array}{l}\text { No criteria regarding a minimum } \\
\text { duration or intensity of exposure }\end{array}$ & $\begin{array}{l}\text { No details } \\
\text { provided }\end{array}$ \\
\hline Norway & $\begin{array}{l}\text { Histologic examination or on the basis } \\
\text { of radiological data and clinical course }\end{array}$ & Helsinski criteria & 15 years \\
\hline Portugal & X-ray, CT-scan, bronchoscopy, biopsy & Indicative list of works & 10 years \\
\hline Sweden & $\begin{array}{l}\text { Diagnosis based on biopsy or cytology } \\
\text { and X-ray Lung cancer with asbestosis } \\
\text { or exposition criteria }\end{array}$ & $\begin{array}{l}\text { At least } 15-20 \text { years } \\
\text { or above } 10 \text { fibers } / \mathrm{ml} / \text { year }\end{array}$ & 15 years \\
\hline Switzerland & $\begin{array}{l}\text { Diagnosis based on radiological, histological } \\
\text { data or bronchoscopic findings. Recognition if } \\
\text { lung cancer with asbestosis or pleural diseases } \\
\text { or exposition criteria }\end{array}$ & $\begin{array}{l}25 \text { fibers/ml/year } \\
\text { (alternative condition to medical criteria) }\end{array}$ & $\begin{array}{l}\text { No details } \\
\text { provided }\end{array}$ \\
\hline
\end{tabular}

Shipbuilding and repair are the main industry in Brest, a French port located at the Department of Occupational and Environmental Diseases. The workers most exposed to asbestos were involved in this activity. Approximately $90 \%$ of compensated lung cancer patients were current or ex-smokers in the present study. Very few studies described smoking habits in this population (3). A synergistic interaction between asbestos and cigarette smoking is commonly accepted.
A review of 23 studies was in favor of a multiplicative interaction (13). However, the multiplicative effect claimed by Hammond et al (12) has never been replicated and the hypothesis of a model somewhere between additive and multiplicative is the most probable (3). In most European countries, smoking is not involved in the recognition procedure of ARLC (17). However, in Denmark, any doubt regarding exposure of asbestos, heavy smoking leads to rejection of 
the procedure (17). If the patient consumed more than $7 \mathrm{~g}$ of tobacco per day or more than 10 packs a year, smoking was taken into account for the compensation of lung and laryngeal cancer. Those considerations also applied to cases of asbestosis if obstructive airways disease or chronic bronchitis was revealed in the past clinical history (17). However, the smoking factor is never retained in cases of mesothelioma or pleural plaques (17).

Adenocarcinoma was the most prevalent histological subtype in the present study (45.9\%). Excess of adenocarcinoma in ARLC was shown in some studies (3). Nevertheless, recent well-controlled studies failed to show any significant differences between ARLC and non-ARLC (3). Adenocarcinoma is in fact the most frequent type of lung cancer. According to a recent review of the literature, histology has no significant value in determining whether or not lung cancer can be due to asbestos (3).

Notably, thoracic sarcoma was identified in the present study. To the best of our knowledge, if the link between lung carcinoma and asbestos exposure is well established, this is not true about thoracic sarcoma (6,8-11,18-20). Further investigations also identified two non-primary lung origin carcinomas of esophageal and laryngeal origin in the present study with controversial data regarding the association with asbestos exposure in the literature. In addition, there was no histological proof for $6.8 \%$ of the compensated lung cancers, diagnosis being solely based on radiologic data. Metastases of non-ARLC or non-carcinoma tumors cannot be excluded for these cases. In our opinion, histological analysis is a major parameter to evaluate the relationship between asbestos exposure and a lung malignant tumor. It may permit the distinction between a carcinoma of lung origin in which the link with asbestos exposure is well established, and other more doubtful asbestos-related primary or metastatic tumors.

In conclusion, the present results are globally in accordance with other studies on ARLC. Even if the relationship between smoking and asbestos exposure is not clear, the cases reported in the present study strongly argue for the crucial importance of smoking cessation in asbestos-exposed workers.

Thus, histological data have to be considered to evaluate the potent relationship between asbestos exposure and lung malignancy. Indeed, although the relationship between asbestos and lung carcinoma is well established, it is insufficiently proven regarding non-carcinoma type and/or cancer from extra-pulmonary primitive origin, except for mesothelioma.

\section{Acknowledgements}

The present study was supported by 'La Ligue contre le cancer CD29'. We would like to also acknowledge 'Omnium group' for financial support and the pathologists of Brest and
Local tumor tissue biobank BB-0033-00037 ('CRB Santé', CHRU Brest) for their collaboration in the present study.

\section{References}

1. Eurogip: Cancers d'origine professionnelle: Quelle reconnaissance en Europe? http://www.eurogip.fr/images/publications/ EUROGIP_RapportRecoCancerspro_49F.pdf. Accessed April 25, 2010.

2. Tossavainen A: Asbestos, asbestosis, and cancer: The Helsinki criteria for diagnosis and attribution. Scand J Work Environ Health 23: 311-316, 1997.

3. Nielsen LS, Bælum J, Rasmussen J, Dahl S, Olsen KE, Albin M, Hansen NC and Sherson D: Occupational asbestos exposure and lung cancer - a systematic review of the literature. Arch Environ Occup Health 69: 191-206, 2014.

4. Auerbach O, Garfinkel L, Parks VR, Conston AS, Galdi VA and Joubert L: Histologic type of lung cancer and asbestos exposure. Cancer 54: 3017-3021, 1984.

5. Hiraoka K, Horie A and Kido M: Study of asbestos bodies in Japanese urban patients. Am J Ind Med 18: 547-554, 1990.

6. Johansson L, Albin M, Jakobsson K and Mikoczy Z: Histological type of lung carcinoma in asbestos cement workers and matched controls. Br J Ind Med 49: 626-630, 1992.

7. Warnock ML and Isenberg W: Asbestos burden and the pathology of lung cancer. Chest 89: 20-26, 1986.

8. Anttila S, Karjalainen A, Taikina-aho O, Kyyrönen $\mathrm{P}$ and Vainio H: Lung cancer in the lower lobe is associated with pulmonary asbestos fiber count and fiber size. Environ Health Perspect 101: 166-170, 1993.

9. Hillerdal G, Karlén E and Aberg T: Tobacco consumption and asbestos exposure in patients with lung cancer: A three year prospective study. Br J Ind Med 40: 380-383, 1983.

10. Sluis-Cremer GK: The relationship between asbestosis and bronchial cancer. Chest 78 (Suppl): 380-381, 1980.

11. Weiss W: Lung cancer and occupational lung disease. Clin Chest Med 2: 289-300, 1981.

12. Hammond EC, Selikoff IJ and Seidman H: Asbestos exposure, cigarette smoking and death rates. Ann N Y Acad Sci 330: 473-490, 1979.

13. Lee PN: Relation between exposure to asbestos and smoking jointly and the risk of lung cancer. Occup Environ Med 58: 145-153, 2001.

14. Erren TC, Jacobsen M and Piekarski C: Synergy between asbestos and smoking on lung cancer risks. Epidemiology 10: 405-411, 1999.

15. Samet JM, Epler GR, Gaensler EA and Rosner B: Absence of synergism between exposure to asbestos and cigarette smoking in asbestosis. Am Rev Respir Dis 120: 75-82, 1979.

16. Ahn YS and Kang SK: Asbestos-related occupational cancers compensated under the Industrial Accident Compensation Insurance in Korea. Ind Health 47: 113-122, 2009.

17. Eurogip: Les maladies professionnelles liées à l'amiante en Europe. http://www.eurogip.fr/images/publications/EUROGIP24F-MPamiante.pdf. Accessed March, 2006.

18. Hourihane DO and McCaughey WT: Pathological aspects of asbestosis. Postgrad Med J 42: 613-622, 1966.

19. Raffn E, Lynge E and Korsgaard B: Incidence of lung cancer by histological type among asbestos cement workers in Denmark. Br J Ind Med 50: 85-89, 1993.

20. Whitwell F, Newhouse ML and Bennett DR: A study of the histological cell types of lung cancer in workers suffering from asbestosis in the United Kingdom. Br J Ind Med 31: 298-303, 1974. 